\title{
Education: Traditional Vs. Modern Perspective
}

\author{
Sofe Ahmed ${ }^{1}$ \\ $\mathrm{PhD}$ Fellow, Islamic University of Kushtia
}

\begin{abstract}
Education is a sign and gift of the development and progress of human civilization. It simply functions to transmit a nation's historical, cultural as well as moral values (Sattar, 1982:12). It is also viewed as a subsystem of the total systems of the society that influences or is influenced by various social institutions, and ideologies like religion, family, state, politics, community, or social stratification (Buch,1974:92).However, thousands-years old human civilization has developed a universal definition or concept of education. Consequently, whenever any fallacy or phony practice is noticed in the case of education, it fairly becomes vivid to every conscious and educated man of every society. They can distinguish what is education and what is not. Here is a matter of deep concern regarding education in modern time that the absence or lack of emphasis on various fundamentals or basic aspects of education in modern curriculum. Studies and evaluation of syllabuses of different higher educational institutions, particularly of Bangladesh show that there is little or zero emphasis on the moral values of education in the programs of graduation and post graduation specifically. Curriculum designers seem to be too much technical or mechanical in their approach of designing curriculum. This tendency of over emphasis on technical or so called job oriented education misguides them to avoid covering the fundamentals or basic concepts of education while designing the syllabus. As a result, a kind of educational anarchy is going on in the realm of modern education. Learners are going far from attaining the essential purposes of education. They little think and care about what the goals and functions of education and an educated citizen are. They fail to fulfill what society expects from educated society. The society is thus also deprived from their expectation of benefit education and services of educated class. The current study is an effort to focus on what the actual concepts of education are and what is going on in modern practices of education in Bangladesh. Finally, it tries to find some solutions to bring the educational practices back to its origin or track to achieve the purposes of education.
\end{abstract}

\section{INTRODUCTION}

The existence of any modern and progressive society can never be imagined without education. The meaning, purpose, and functions of education suggest that it is such a fundamental and inevitable need for human life, which distinguishes the life and identity of humankind from that of animal or all the other creatures of Allah Almighty. To some educationists the word education is derived from Latin word educatum meaning to teach, or to train. Some others find that education comes from Latin word educare, which means to lead out, to draw out, to take care etc. A few specialists think that the word education is originated from Latin word educere meaning to bring up, to train, to mould, to lead by giving instruction, to develop the inner capacity or dormant talents, to change from within, to teach according to need and necessity (Uddin and Das;2006:7). However, though here the word educere seems to be wider than educatum and educare, but all the three words are interconnected regarding the meaning of education. Hence, education can be seen as the combination of the three; educatum, educare and educere. And depending on the interpretation of these three words it is said that education from its origin is that what aids the development and expansion of the physical, mental, as well as inner capacity and strength of a human child. Swift (1970:217) defines the functions of education as to maintain and to change society at the same time. Plato says, education develops in the body and the soul of the pupil all the beauty and all the perfection he is capable of. Aristotle says, "Education is the creation of sound mind in a sound body. It develops man's faculty specially his mind, so that he may be able to enjoy the contemplation of supreme truth, goodness and beauty in which perfect happiness essentially consists". To Adams "Education is a conscious and deliberate process in which one personality acts upon another in order to modify the development of the other by the communication and manipulation of knowledge". Educationist Nunn treats education as the complete development of individuality of child, so that he can make an original contribution to humanity according to the best of his capacity. John Dewey says that education is the process of living through a continuous reconstruction of experience. It is the development of those entire capacities and environment of the individual, which will enable him to control his environment and fulfill his possibilities. Rabindranath Tagore says, "Education should be in full touch with our complete life-economical, intellectual, aesthetic, social, and spiritual"

\footnotetext{
${ }^{1}$ Corresponding Author: sofeahmed@gmail.com
} 
(Uddin and Das; 2006:13). In sum and substance, education is the way of developing human beings' mind, body, soul, understanding, attitudes, and all other humanly features, which man needs to lead his personal, family, social, economic and political life and to accomplish all the responsibilities as a rational, civilized, and the best creation of Allah Almighty.

But unfortunately the practices of modern higher educational institutions particularly in Bangladesh don't seem to put emphasis on the above mentioned basic issues or fundamentals of education. Society doesn't find differences between educated and ignorant class in terms of their attitude, actions, and behavior etc. Consequently the society is getting frustrated regarding education and its function. In short, the current practices of education particularly at higher level in Bangladesh have gone far from the actual concept of education why modern education fails to produce expected educated class or citizens. This study will evaluate this gap in order to find out some probable solutions to overcome the existing crisis in achieving the universal goals of education through educational practices of current modern time.

\section{TRADitional OR UNIVERSAL CONCEPT OF EDUCATION}

Education is one of the foundations of human civilization. Educationists have viewed education and it's the scope in different ways. Views of thinker differ from time to time. Some of the experts of education view education in narrower sense and some other in wider sense. Though the definitions and opinions of experts regarding education vary, but they all strongly agree in terms of fundamental functions, goals, and characteristics of education. In other words, there are fundamental characteristics or universal concepts of education that none of the educationist can deny. If we look at the following definitions of education given by specialists, those similarities or common notions of education will be vivid to us

\begin{tabular}{|c|c|}
\hline Educationist/Expert & Definitions \\
\hline Plato & $\begin{array}{l}\text { It (Education) develops in the body and soul of the pupil all the beauty and all the } \\
\text { perfection he is capable of. }\end{array}$ \\
\hline Nunn & $\begin{array}{l}\text { Education is the complete development of individual of the child, so that he can make } \\
\text { an original contribution to human according to the best of his capacity. }\end{array}$ \\
\hline Aristotle & Education is the creation sound mind in a sound body. \\
\hline John Locke & The purpose of education is to build up one's character \\
\hline Rabindranath & $\begin{array}{l}\text { Education should be in full touch with our complete life-economic, intellectual, } \\
\text { aesthetic, social, and spiritual }\end{array}$ \\
\hline Adams & $\begin{array}{l}\text { Education is a conscious and deliberate process in which one personality acts upon } \\
\text { another in order to modify the development of the other by the communication and } \\
\text { manipulation of knowledge. }\end{array}$ \\
\hline Amez Uddin and Das & $\begin{array}{c}\text { Education is complex process of development .It helps the spiritual and social } \\
\text { development of individual's life. Religion helps leading a complete life by } \\
\text { developing one's spirituality. Hence, goals of education and religion are same and } \\
\text { parallel. }\end{array}$ \\
\hline Gandi & $\begin{array}{c}\text { By education, I mean an all round drawing out of the best in child and man's body, } \\
\text { mind, and spirit. }\end{array}$ \\
\hline $\begin{array}{l}\text { Dr. Bashir Ahmed \& Sofe } \\
\text { Ahmed }\end{array}$ & $\begin{array}{l}\text { In sum and substance, education is the way of developing human beings' mind, body, } \\
\text { soul, understanding, attitudes, and all other humanly features, which man needs to } \\
\text { lead his personal, family, social, economic and political life and to accomplish all the } \\
\text { responsibility as a rational, civilized, and the best creation of Allah Almighty. }\end{array}$ \\
\hline
\end{tabular}

(Uddin and Das;2006)

If we analyze the above mentioned notions of education, we find some common characteristics of education like spiritual and psychological development, contribution to society or human development etc. that all educationists acknowledge. Educationists don't differ in terms of common goals and functions of education. All of them expect attitudinal, physical, and psychological changes in persons who undergo the process of education. They view education as the process of individual and social development. On other hand ignorance is seen as darkness. People can get of this darkness through the light of education. Ignorance leads towards inhumanity. In other words, man fails to act as human or acts as animal because of ignorance. Because of this ignorance, a man disqualifies to be a complete man though he/she has mannish physical appearance. Hence, man after being born as human being needs to be complete man through education or it is education that indeed makes a human being real man. Education gives him or her characteristics which differentiate him or her from other creations as well uneducated beings. 


\subsection{Modern Bangladeshi Reality Or Practices Of Education}

The reality of the output of modern education in Bangladesh shows that the current practices of education fail to achieve the universal goal of education. When we the educated class is more involved in corruption, acid throwing, hijack, terrorism, even rape etc. than ignorant man, people fail to find out the meaning and role of education in man's life. If education is supposed to bring changes in man's life, where is the change? If education distinguishes man's behavior, approaches and, attitude from that of ignorant beings' where is the difference? If education prepares man to contribute to society and civilization why are their actions so uncivilized? Possibly, for this reason Rabindranath Tagore has bitterly criticized the limitations of modern education system introduced by British in this country. He opines that the existing education fails to enable us thinking and working skillfully. This system of education is not only incomplete but also mechanical as well as dull. The current education is accused of providing some unsatisfactory livelihood but not life (Uddin and Das; 2006). There is huge scarcity of moral values in the practices of modern education. Though it partially covers some aspects of education, but fails to fulfill the fundamental requirements of education. It is failure to produce a complete man of education covering material as well as ethical value.

\subsection{The Gap}

The main gap of present practices lies with learners' orientation to education. Authority of education particularly curriculum designers and teachers fail to introduce the learners to the actual goal of education. The existing curriculum is seen too much oriented to the material or technical values and aspects of education where moral or spiritual aspects are consciously or subconsciously ignored. Where approximately fifty courses are taught in a fouryear program in university, here there is no single course to cover the moral or spiritual aspects of education to prepare learners' psyche and build up their moral courage to uphold humanity and serve the society. We may have a look at the courses of different programs offered by typical Bangladeshi universities.

An overview of Programs offered by different universities in Bangladesh

\begin{tabular}{|c|c|c|c|c|}
\hline Program & Courses & Credit & Area of Study & Remark \\
\hline BSCSC & 46 & 132 & Science & \\
\hline Architecture & 82 & 122 & Science & \\
\hline BSC in Civil \& Environment Engineering & 58 & 137 & Science & \\
\hline
\end{tabular}

(http://www.northsouth.edu/academic/2/121/bs-in-civil-and-environmental-engineering.html)

\section{THE RECOMMENDATION AND CONCLUSION}

By analyzing the reality of the modern practices of education in Bangladesh particularly of higher level, the attitude and notions of its people, we can undoubtedly conclude that it will not be possible to achieve the goals of education until the curriculums of higher educational institutions are reformed covering the fundamental aspects of education like ethical and spiritual values based on the social customs, norms, values beliefs, and demand of people of this country which are extremely related to religion. It is never possible to ignore the ideas and demands of the current science and technology oriented trend of education, but it would be a partial and inadequate approach if we ignore the fundamental moral and spiritual values of education in the name of emphasizing on science and technology in education system. Besides, the nation will not get rid of current suffering, though the ratio of education will be increasing. However in order to overcome the gap or drawbacks of modern practices of education in Bangladesh ,the authority of education of the country can take necessary action considering the following specific recommendations.

1. Syllabus of educational institutions particularly of higher level should be reformed according to the philosophy, principles, and characteristics of universal concept of education, and based on the actual religio-social values, conditions, norms, and beliefs of the mass people of this country.

2. Changes in the philosophy of designing curriculum are must. Curriculum designers must be selected cautiously from those educationists who are well introduced with the universal goal ,and functions of education

3. No political influence should work while selecting the designers of curriculum, and only expertise in the field of education should be considered as the requirement of being selected as a curriculum designer.

4. Teachers must be trained up according the spirit of reformed syllabus and should be instructed to implement the reformed principles accordingly. Finally, their practices of reformed education values should also be rigorously and regularly monitored through teachers' perform appraisal reports etc. 
American Research Journal of English and Literature, Volume 1, Issue 2, April 2015

ISSN 2378-9026

\section{REFERENCES}

[1] Buch, M. B. (Ed). 1976. A Survey of Research in Education, Baroda; CASE, M.S. University of Baroda.

[2] Sattar, Ellen. 1982. Universal Primary Education in Bangladesh. The University Press Ltd, Dhaka, Bangladesh.

[3] Swift, D.F. 1970. Basic Reading in the Psychology of Education. London: Routledge and Kegan Paul.

[4] Uddin, Md. Amez and Das, Shuvash Chondro. 2006. Shikkha Dhorshon (Philosophy of Education.) Ghyan Kosh Prokashoni, Dhaka, Bangladesh.

[5] http://www.northsouth.edu/academic/2/121/bs-in-civil-and-environmental-engineering.html 